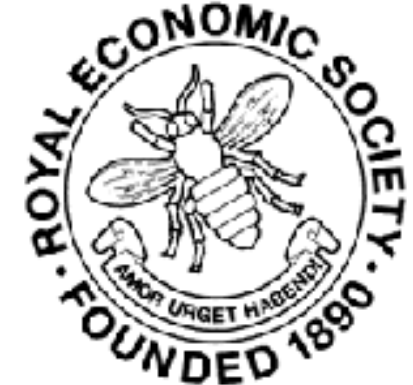

Municipal Industries and the Ratepayer

Author(s): William Smart

Source: The Economic Journal, Vol. 11, No. 42 (Jun., 1901), pp. 169-179

Published by: Wiley on behalf of the Royal Economic Society

Stable URL: http://www.jstor.org/stable/2957147

Accessed: 14-03-2015 23:39 UTC

Your use of the JSTOR archive indicates your acceptance of the Terms \& Conditions of Use, available at http://www.jstor.org/page/info/about/policies/terms.jsp

JSTOR is a not-for-profit service that helps scholars, researchers, and students discover, use, and build upon a wide range of content in a trusted digital archive. We use information technology and tools to increase productivity and facilitate new forms of scholarship. For more information about JSTOR, please contact support@jstor.org. 


\section{MUNICIPAL INDUSTRIES AND THE RATEPAYER}

To the economist the modern state is a real though unconscious co-operation of mutual service. Every one of us, whether in a trade or a profession, and whether he "earns a bare living" or "makes money," makes goods to sell ; each man's supply of goods is his demand for the goods supplied by other men; and the income we get is the price we receive for our contribution to the great stream of wealth which flows into and through the lives of the people. In short, the wages, salaries, interest, profits, rent into which the National Income is divided, are the payments made to those who own the various factors by which the National Income is produced. It is not, however, always noticed that, among the economic organisations where the labour and capital of the community are put together to produce goods, the largest is the Government and the next largest is the City.

The democratic idea of a Government is that of a great manufacturing and distributing organisation-a committee of ourselves, which we incorporate and instruct to provide certain services to our order, such as postal services, army and navy, law and justice, public education. The goods thus produced, like the other goods produced in smaller organisations, form part of the National Income, and are reckoned as such in statistical statements, where the income of government servants appear alongside the incomes of factory owners and the like. ${ }^{1}$ The goods thus provided we buy: some of them, such as postal service, we pay for on the ordinary principles of free sale; but the great bulk we pay for by our taxes. In either case the payments are not contributions from our capital, but sums paid out of our individual incomes for value received-part of our household expenses as much as is our butcher's bill. In another place ${ }^{2} \mathrm{I}$ have set forth the view

1 See Sir Robt. Giffen's tables in the Growth of Capital, and in the writer's Distribution of Income.

2 The Taxation of Land Values and the Single Tax. 
that a tax is a price-in spite of the fact that the price has no direct relation either to the cost of the service or the benefit received individually, but is proportional to the income of the taxpayer: that, in short, we pay for our Government goods as we pay our doctor, or as the dissenter pays, at the plate, for his church services.

Similarly, the City is a smaller organisation, instructed by the rate-payers to provide certain local services. And the rates also are Prices ; payments for value received taken out of current income. But in the method of payment there is this difference ; not only that there is no indirect taxation, but that the price paid is assessed not by declared but by presumed income, rental being taken as its visible sign and measure.

The citizen and the rate-payer, however, stand in a double relation to the Government and the City. They are not only buyers of the goods which these great corporations supply, but members of these corporations. In this latter relation, the Government strikingly presents the economic features of a great Joint Stock Company, the citizens being the subscribers. It has a mortgage debt for money borrowed on capital account, which is being paid off by the sinking fund included in the $£ 23,000,000$ that form the first item in the Consolidated Fund. Deducting this, all the wealthin the country is its capital. But the capitalis not paid up. It need not be, as its credit is unlimited, and as it gets in the most of its revenue before it renders its services. And its liability is unlimited, extending to our persons as well as to our fortunes. Thus, of course, this great company pays no dividends. Although the total capital of the government is the total wealth of the people, it is not "share capital," and we call the citizens subscribers, not shareholders. It is impossible to pay dividends, unless the capital is allotted. ${ }^{1}$ A City again is a smaller joint stock company on the same model, with a mortgage debt repayable by sinking funds, with a capital uncalled, with a liability limited by Parliament in some departments, unlimited in others.

Thus the rate-payers, like the tax-payers, stand in two distinct relations to their governing body:-they are customers and they are subscribers-like shareholders of a Limited Liability Company who buy all the goods made by it, or subscribers to a mutual Insurance Company.

${ }^{1}$ As the functions of government extend beyond its economic ones, the voting power which controls the management is conditioned by other considerations than the purely economic. But the above at least suggests one economic reason why the voting should not be according to amount of property held. 
Now it may be granted that there is no ring fence defining the services which either of these bodies may be asked to render. Not only is there no clear line which separates government from municipal services, but many of the functions now undertaken, with full consent, by both have been taken over from private enterprise within the last century-the typical cases being respectively Public Education and Police-and great bodies are continually agitating that land, railways, \&c., should be similarly taken over. Moreover, many industries which are monopolised by governments and municipalities here, are private enterprises in other countries. But it is not always noticed, I think, that neither body can extend its services without bringing the tax-payers or rate-payers under certain responsibilities as subscribers of the necessary capital. It is this double relation which I propose to consider in connection with the comparatively new phenomenon of Municipal Industries, where the relations are peculiarly complex.

Instead of reviewing activities already undertaken by municipalities, let us look at the bearing of what has been said on some of the proposals now being made for the extension of municipal functions. And, to avoid the heated atmosphere of schemes generally under discussion, let us take proposals which have not yet been put forward by more than one or two municipalities.

If it be true that there is no hard and fast line of separation. between municipal and private industries, there seems no prima facie reason why a Municipality should not extend its functions in the direction of what are properly called Industries. But these various extensions affect very various interests, and involve very various liabilities.

The sphere of a Government is comparatively definite. It generally provides services such as all civilised governments provide and have provided for centuries. As these services are of almost universal use; as they are monopolies; and as it is. impossible to allocate the individual benefit obtained, the great. bulk of them are appropriately paid for on what may be called the doctor's bill principle. But it also undertakes one great service which is distinctively and indubitably an industry, the Post Office, and it charges for the goods provided on an entirely different principle, namely, on the ordinary commercial principle of sale.

When, however, we turn to a City, we find a comparatively new body, whose functions have never been defined, We find it 
rendering a great mass of common services, and appropriately charging for them on the doctor's bill principle. But we also find it ambitious of entering on other more or less sectional undertakings and industries, which would be quite appropriately paid for on the principle of the penny stamp. In short, what is the small field in government provision promises to be the large field in municipal provision. We find, moreover, that it entertains some idea of charging for some of these latter services, not on the principle of the penny stamp but on the principle of the doctor's bill, and this seems to me to require careful examination. That is to say, we are being asked as it were to provide a local and even sectional postal service, and charge for it by a local income tax.

To make this clear. It is obviously one thing (A) for a Municipality to start milk shops and coal depots, where we can buy our milk and coals or not buy them as we wish. It is another thing (B) for a Municipality to monopolise the telephones, so that, if we want a telephone, we must pay the Municipality's price. It is a third thing (C) for a Municipality to start public libraries, which we are not to pay for as and when we use them, but to pay whether we use them or not, and, moreover, to pay according to our ability.

(A) The Municipality may add to its functions without making a monopoly of the industry. It may, for instance, sell milk.

As regards this, it is not a valid objection that those who pay the piper should call the tune, and that a burden should not be put on the ratepayers without an unmistakable mandate from them. For the ratepayers generally do not pay the piper. The people who pay are the people who buy the milk. It is not using public money for a sectional purpose, because no capital is called up. The capital is borrowed by the Municipality from individuals, as it were on debentures. It is quite true that interest must be paid on this capital and a sinking fund established, but both interest and sinking fund come out of the price of the milk. The only thing that may be urged is that, in case of failure, it would not be possible to add to the price of municipal milk so long as it was of the same quality as and competed with the milk sold by ordinary dealers: in this case capital would be called up from us all in the shape of a levy. There is, besides, the danger that both the loss and the levy might be disguised by questionable bookkeeping, conscious or unconscious, and the industry be carried on. Further than this, the citizens are not interested as subscribers and ratepayers. 
The next obvious consideration is that in such a case the Municipality comes into competition with a section of its own citizens, and it will generally be granted that a Municipality should not undersell. But the expression "underselling" is ambiguous. There are very good reasons why a Municipality should not undersell so as to lose money, for, as I said, in this case the loss must ultimately come upon the ratepayers in the shape of a levy, and this would be using public money for sectional purposes, and, moreover, making the ratepayer pay, not pro rata, but according to his income. But, it is said, a Municipality may undersell and yet not lose money, because, as a Municipality, it can borrow its capital more cheaply. Thus it uses the uncalled-capital of the ratepayers-among whom are the milk dealers - to lower its cost of production, and, in this case, it competes unfairly with a section of the ratepayers who have no such advantage. This section of the ratepayers, then, is compelled to provide a stick to break its own head. There is some force in this, but not, I think, so much as it is usually credited with. It is true as regards men with small capitals: it is more doubtful as regards those whose security is ample. And, to this extent, it is equally an argument against people with large capitals going into the milk trade at all. It is open to the suspicion of being a plea for small dealers and high prices.

But there is a way of underselling that does not necessarily express itself in loss. If members of a Municipality give their services to such an industry for nothing, and so are able to undersell without loss to the ratepayers (because they provide the service for which profits are paid in ordinary business and give away the profits in the price of the milk), then I think there is a valid objection. In this case the Municipality is favouring the milk-consuming section of the community, and hurting a section of its own citizens, the private milk dealers. It is not using public money, but it is using public men; and the contention is quite valid that the councillors were put in their position to do work for us all and not to devote themselves to the benefiting-or hurting - of one class.

The conclusion would seem to be that, in such a case, the Municipality must include ordinary profits among its costs. ${ }^{1}$

1 This is the conclusion arrived at by Mr. Uannan (Economic Journal, March 1899) from another point of view than that of fair competition. His argument is (1) that, to insist on any surplus being applied in reduction of price of the commodity, is to encourage wasteful management by removing the check of comparison with private enterprise ; so making the management less keen in their economies, and more susceptible of pressure as regards wages and salaries; and (2) that, if an 
This is not in the least a contention that a Municipality should aim at making profits in order to relieve taxation-that is another question, as it is indirect taxation-but a plea for fairness to the private eitizen with whom it competes. It may be added that, if any Municipality comprised a fair representation from all the interests and trades, such underselling would have little chance of being allowed.

But, in the case of unmonopolised industries, this need not be very much insisted on. It would no doubt be a very good lesson in democracy to see the Lord Provost and Magistrates-in their robes-selling milk across the counter: but when they do their work by deputy, employing managers and foremen and saddling them with responsibility, it does not seem that the profit they save could ever be enough to allow them to undersell the private milk dealers. The question, indeed, is not how much the milk dealers stand to lose by it, but how much the community may be expected to gain.

Some convincing reason must, of course, be given for the Municipality taking up another industry at all. There is always the preliminary question whether the time and strength of its members are not. already taxed to the utmost by the functions already performed; and, after that, the question why the Municipality should take on its shoulders a business risk which private employers are willing to take on theirs. Further, granting that the members of the municipality have time and ability to take on more work, and that the risk is more than balanced by the probable gain, reason must be shown for the Municipality taking up one industry in preference to another. ${ }^{1}$ But, in cases where

industry is undertaken at all, the only way to avoid giving a sectional benefit (that is, to the consumers of the commodity) is to make a profit and spread it over the citizens generally in reduction of rates. The consumers in this case do not lose, as they get the commodity, presumabjy, at the same price as they would have had to pay to private producers; and they gain just as the community gains, in the reduction of rates, due to an activity which should be exerted, if at all, for the common benefit.

1 The reason alleged must be more than the mere necessity of the proposed provision to human life or health. The starting of a milk supply is generally advocated, for.instance, on the ground of the necessity of pure milk and cheap milk for the health of the growing generation. It would require to be shown in this case that the present supply is not pure; which, again, suggests the question whether there is not a failure of supervision and inspection that might be cured by enforcement of powers already in the Municipality's hands. Further, it would require to be proved that it is the dearness of milk which prevents the children getting enough, and not the foolishness, idleness, or carelessness of the parents. (It. might be found, for instance, that mothers who made the excuse of dear milk, were giving their children dearer food because it was "handy." I have heard of a mother who answered the remonstrance of a medical man against her feeding her 
it is considered that there is a failure of private enterprise to provide some article of vital importance to the community, I see nothing to urge against it-always providing that the article is not sold under cost. All that it amounts to is that the Municipality, in such a case, provides an object-lesson, and sets a standard for private dealers to adopt.

(B) The Municipality may add to its functions by taking over an industry and making it a monopoly. This it dres in the case of the Tramways.

In this case also, it will be noted that we cannot object as subscribers. The Municipality is not calling up our capital, except, as before, in the case of failure. Nor can we object that we are compelled to pay for goods we do not want, for practically everybody uses the cars. If we have a complaint, it is merely that we have to pay the Municipality's price every time we use the cars. And, as a car service must always be somebody's monopoly, this is not a very valid objection.

But what is the object of a Municipality taking over and monopolising an industry? It cannot be to set an object-lesson to private makers, for the private makers are first swept out of existence. The contention must be one of three: either first, that it can do the work better or more cheaply; or, second, that the business affects too many interests to be allowed to remain in private hands; or, third, that the city should share in the profits of monopoly. To take these in order.

(1) The contention may be that the Municipality can do the work better or more cheaply. Theoretically it may, as municipal service means large production with its peculiar economies. It is the same argument as appears on the prospectuses of the large combinations of capital. On the other hand, the contention is not always borne out by the results of these combinations. They may not raise price: they do not often, as they should, reduce it. Economies, in short, do not always make for economy. It is a very plausible contention that the municipal monopoly of electricity has kept electrical provision so far behind in this country.

Apart from this, the difficulty is, that, to acquire a monopoly, a Municipality generally has to interfere with what are called "vested interests." I readily admit that the expression "vested interests"-like the expression "landowner"-carries a quite undeserved odium with it. They are, generally speaking, interests

baby with beef by "What am I to do? he won't take pork"). And, granting this, it would require to be proved that more milk could be sold for a penny without selling below cost. 
that have grown up, quite legitimately, on the expectation that what the community, through law and custom, has allowed and sanctioned for long periods, it will not wantonly interfere with. But whether a Municipality should interfere with vested interests or not, is all a question of the public good-whether the interest to be acquired is greater or less than the interests to be interfered with. One thing, however, seems obvious: that the new monopoly should not punish the free private industries which preceded it. A Municipality, as a rule, has little initiative. Usually it is private individuals who lead the way, and build up the industry which it may then become desirable for the Municipality to take over. In this case, the pioneers should not be treated as persons to be bought up at the lowest price which their helpless position compels them to take, but as citizens who have deserved well of the community.

Granted this condition, I am unable to see why a Municipality should not monopolise any industry, if it can do it better or more cheaply than private enterprise.

(2) The contention may be that the industry in question affects too many interests to be a fit subject for private enterprise and private profit. This seems a valid argument, for instance, as regards any undertaking which involves control of the streets, seeing that anything which tears up the streets affects those who use the streets and affects the trade of the shops which line the streets. The streets, in fact, are property for whose making and maintenance we pay rates; and if, after this, the streets are allowed to be abused for private profit, we ratepayers have very good reason to complain. For the Municipality to take over such a business, seems to me a natural extension of recognised functions.

(3) The contention may be that a city should share in the profits of monopoly. This seems perfectly sound if the Municipality can legitimately get hold of the monopoly in its early stages. But if it allows the monopoly to grow up under its sanction without protest, and then buys it at market value, the profits of such a monopoly are not likely to be very great. If, however, it employs compulsion, and buys it under market value, and if the business is one whose shares have been freely bought and sold and are at any moment in the hands of many who have paid the full market price, this is confiscation, and probably confiscation from those who have never had any monopoly profits.

It may further be pointed out that, when monopolies are in private hands, they generally break down before very long, where- 
as, when a Municipality takes over a monopoly, the monopoly is likely to be perpetuated.

(C) A Municipality may add to its functions by taking over an industry and putting the payment upon the rates. Here, I think, emerges a distinct line of cleavage. For in this case we are all interested, and interested in the two relations-as sub. scribers providing the capital, and as purchasers paying on the doctor's bill principle.

First, of our interest as subscribers. It should be quite clear that this is an entirely different case from those previously considered.

If the city borrows capital to start milk shops, it does not call up capital; it borrows, as I have said, on mortgage; the ratepayers have neither to pay interest nor sinking fund, for these are borne by the buyers of milk-unless in the case of a deficit. If it borrows to start a gas supply, it is the same, except that, if there is a deficit in any year, the price of gas may be raised on the consumers of gas, and no one else suffers. But, when a private undertaking is taken over by a Municipality, and the payment is put on the rates, then, although the capital is raised primarily on mortgage, yet all who pay rates pay not only the annual interest but pay back the mortgage gradually in the sinking fund. In short, in this case a part of our capital is called up, and we subscribe this levy of capital not pro rata, but in proportion to the size of our incomes.

Second, of our interest as purchasers. To illustrate this, take the proposal now before the Municipality of Glasgow, of Free Ferries across the Clyde. I take this proposal because of its obvious plausibility. The city is almost equally divided by the river. In the upper reaches there are many bridges, but the bridges stop where the shipping and the docks begin. Bridges are roads, and, as such, are properly put on the rates. Why not the clumsy, but the only, substitute of Ferries? There can scarcely be a stronger contention than this. Strong as it is, it will repay consideration as a typical case.

What is to be noted is, that each of us will have to pay, not on a calculation of the average number of times he has been in the habit of crossing the river, but according to his ability to pay for things in general: that is, according to his presumed income. And what deserves to be brought out in the clearest terms is that, while this is a sectional benefit, it is paid by a general burden. It is not laying a burden upon the rich for the benefit of the poor, 
but upon the ratepayer, whether rich or poor, for the benefit of a class embracing rich as well as poor. The poor man who never used or never will use the ferries has now to pay according to his rental to subsidise a class. Only those who use the ferries get any value for their money, and, even in their case, it is quite indeterminate whether they pay more or less than they would have paid under the old system. Indeed, it is quite conceivable that the man who gains most by the new rate is the rich shipbuilder who has his house on one side of the river and his yard on the other. $^{1}$

Such, then, are the three groups to which any proposed extension of municipal industry belongs, and such are the considerations which must be taken into account after it has been clearly seen to which of the three it belongs. If this discussion has any value, it is only in bringing out that, according to the group to which the industry belongs, will the municipal provision affect different interests, involve different responsibilities and liabilities, and be open to different objections.

As regards the first two, the chief criticism is, not that they involve the use of public money for purposes that are more or less. sectional, but that it is doubtful how far a committee can manage a business as well as private enterprise, and that the time and energies of our public men are apt to be diverted from fields where their services are more obviously wanted. As regards the third, however, not only is the capital of the ratepayers called up, and that in proportion to their ability to pay, but they are called on to pay sums varying with their income whether they get any benefit or not. This seems to me, as I say, a distinct line of cleavage. Seeing that local rates are the same in principle as Government taxes, such an extension of municipal function should have the justification of the great Government services : it

1 It will be understood, I hope, that I take Free Ferries because they seem to. bring out the particular considerations which must be weighed before putting any new municipal service on the rates. That is to say, I take them as presenting prima facie a sectional service. If any one likes to reply that a ferry is no more sectional than a road in some outlying district of the city, which few people ever use except the workmen of a particular factory, I should admit the argument, and. rather raise the question whether a toll in the one case would not be as appropriate as a charge in the other. In municipal taxation, we do pay for many things which only sections of the inhabitants use or can use : indeed, all municipal benefits are more or less sectional. A better case to illustrate my point would be, say, an. archæological museum, put upon the.rates, while the expense might be appropriately defrayed by payment at the door. The application of what has been said to the housing of the poor is a tempting subject, but must not be entered on at the end of a paper already too long. 
should, in short, be a great non-measurable common benefit, on the model of the police, education, or poor rate. ${ }^{1}$

To ask that a sectional benefit be put upon the rates, is always open to the suspicion of being an attempt to make the rich pay for the poor. Now we must distinguish between equity of taxation and charity. It is only equitable that the rich should pay more than the poor for a service which affects them both and is not measurable to either ; and this is recognised both in proportional and in progressive taxation. It is not really paying more at all : it is paying approximately the same in burden or sacrifice.

But to go beyond this, is to enter on another field. It is to limit the strictly moral sphere by making charity compulsory, and, moreover, making it compulsory on men who may themselves be poorer than the class who get the benefit. It is quite illegitimate, from the point of view of taxation, to fine the rich because he is rich. The proposal could come only from those who consider the present distribution of wealth the outcome of force or fraud. It is equally illegitimate to charge a poor ratepayer for a benefit which he demonstrably does not receive: and both these are done if the payment of purely sectional services is put upon the rates. For any class to ask this for itself, is to ask for poor relief.

\section{WILLIAM SMART}

1 It is not always noticed that, to exempt certain institutions from the rates, is to put them, in part, on the rates ; - to compel the ratepayers to give a contribution proportional to their rental-income, generally without the question ever being raised whether the institution is or is not of the nature of a common benefit. 